\title{
Immunization of grouper, Epinephelus coioides, confers protection against a protozoan parasite, Cryptocaryon irritans
}

\author{
Apolinario V. Yambot ${ }^{\mathrm{a}, \mathrm{c}}$, Yen-Ling Song ${ }^{\mathrm{a}, \mathrm{b}, *}$ \\ a Institute of Zoology, National Taiwan University, Taipei 106, Taiwan, ROC \\ b Department of Life Science, National Taiwan University, Taipei 106, Taiwan, ROC \\ ${ }^{c}$ College of Fisheries-Freshwater Aquaculture Center, Central Luzon State University, Nueva Ecija, Philippines
}

Received 28 January 2006; received in revised form 31 May 2006; accepted 31 May 2006

\begin{abstract}
The present study aimed to determine whether protection is conferred by immunization of grouper, Epinephelus coioides, against a protozoan parasite, Cryptocaryon irritans. The immunization of $E$. coioides was carried out by a low level exposure of fish to live $C$. irritans theronts from predetermined number of tomonts and by an intraperitoneal injection of a vaccine consisting of formalin-killed C. irritans theronts.

Mucus titers detected by ELISA were significantly higher in fingerling and adult grouper subjected to the low level of exposure to $C$. irritans theronts at 3-week post-exposure compared to fish that had no previous exposure. In addition, significantly smaller tomonts were produced from adult grouper after three successive exposures than the tomonts produced after a single exposure to the parasite.

In the vaccine-immunization experiment, no mortality was monitored in fish that received high dose vaccine $(100 \mu \mathrm{g} /$ fish $)$, while $40 \%$ cumulative mortality and $100 \%$ cumulative mortality were recorded in low dose group (10 $\mu \mathrm{g} /$ fish) and control group (PBS-injected), respectively. In the succeeding replicate, the vaccine-immunized group (high dose) had $37.5 \%$ cumulative mortality and $100 \%$ cumulative mortality for the control. In addition, a total of 1830 tomonts were collected at 5-day post-challenge from the control group while none from the vaccine-immunized group. Significantly fewer trophonts and tomonts were enumerated at 5-day and 7-day post-challenge, respectively, in the vaccine-immunized group than the control.

Results suggest that a protective immunity has been conferred on the immunized grouper as indicated by high antibody titers in the mucus of $C$. irritans-exposed fish and higher survival and fewer parasites in vaccine-immunized fish than the control groups. The conferred immunity played a major role in preventing or limiting the adhesion, invasion, and development of $C$. irritans theronts on the skin of the immunized grouper.
\end{abstract}

(c) 2006 Elsevier B.V. All rights reserved.

Keywords: Immunization; Epinephelus coioides; Cryptocaryon irritans; Vaccine; Exposure; ELISA

* Corresponding author. Institute of Zoology, National Taiwan University, Taipei 106, Taiwan, ROC. Tel.: +886 23366 2455; fax: +88622366 0243 .

E-mail address: song@ntu.edu.tw (Y.-L. Song).

\section{Introduction}

The ciliated protozoan parasite Cryptocaryon irritans invades the skin, eyes and gills of host fish and causes white spot disease in marine fishes. The parasite is attracting attention worldwide because of damage it can 
pose to aquaculture. Mortality of fish with the white spot disease is not uncommon. The parasite has been taxonomically reassigned with a new family name Cryptocaryonidae recommended (Wright and Colorni, 2002). Aquarium fishes, wild fishes and cultured species are included in the list of a wide range of hosts of $C$. irritans. In addition, the fish hosts that could be infected by $C$. irritans inhabit bodies of water distributed worldwide such as the Indo-Pacific, the Atlantic, the Persian Gulf, the Red Sea and the Carribean Sea (Colorni and Burgess, 1997). Different strains or isolates of $C$. irritans were characterized by Diggles and Adlard (1997) and Yambot et al. (2003), and it is likely that other strains will evolve. Recently, a low salinity variant of $C$. irritans was identified by Yambot et al. (2003) infecting sea bream Sparus sarba, a marine fish species cultured in 5 ppt brackish water pond in Taiwan, and causing high mortality. This finding has expanded the parasite habitat and the already broad range of hosts of $C$. irritans.

The high value grouper Epinephelus coioides and several other marine fish species are grown commercially in Taiwan. These cultured fishes are not spared from infection by $C$. irritans. The parasite has become a frequent pest in commercial fish farms and is considered as one of the most devastating parasites of marine fishes cultured in temperate and tropical seas (Colorni, 1987; Wright and Colorni, 2002). Rasheed (1989) reported 50\% mortality of tank cultured juvenile brown spotted grouper in Kuwait. Other records include $C$. irritans infection of a range of wild fishes in Australia (Diggles and Lester, 1996) and cage cultured fishes in Japan (Yoshinaga and Nakazoe, 1997). Prevention from the infection by $C$. irritans and treatment are therefore necessary.

An acquired resistance against $C$. irritans has been observed in fish surviving a controlled infection of the parasite or in immunized fish (Burgess and Matthews, 1995; Yoshinaga and Nakazoe, 1997). The immunization of fish by means of a low level exposure to parasite is usually carried out because of insufficient availability of killed vaccine. Earlier works on Ichthyophthirius multifiliis, the freshwater counterpart of C. irritans, have revealed that humoral immunity confers resistance against $I$. multifiliis and acts by immobilizing the theronts (Clark et al., 1987, 1988; Burkart et al., 1990; Clark and Dickerson, 1997; Sigh and Buchmann, 2001, 2002; Wang and Dickerson, 2002; Wright and Colorni, 2002). In addition, an immobilizing antigen was isolated from I. multifiliis and characterized (Dickerson et al., 1989; Lin and Dickerson, 1992; Xu et al., 1995). A manifestation of acquired protective immunity in fish against the parasite $C$. irritans suggests the promise of immunization as a measure in controlling the parasite.
The study therefore aimed to assess whether protection is conferred by an immunization of a commercially important and a high value grouper, E. coioides, against a protozoan parasite, $C$. irritans. The grouper were subjected to immunization by means of a low level exposure to $C$. irritans theronts from predetermined number of tomonts and by vaccination against the parasite. Immobilization of the parasite and antibody titers were assessed in the C. irritans-exposed grouper mucus, in addition to determining the sizes of the parasite produced in the same fish after three successive exposures. Fish mortality and number of tomonts and trophonts were determined in the vaccinated fish.

\section{Methodology}

\subsection{Maintenance of parasite}

We sourced out $C$. irritans-infected grouper $E$. coioides from a live fish market in Taipei, Taiwan. After its exit from the original host, $C$. irritans was maintained using adult or fingerling grouper. The fingerlings (ca. $2.6 \mathrm{~g}$ each) were purchased from a hatchery in southern Taiwan, while the adult (ca. $300 \mathrm{~g}$ each) were procured from a live fish market. Prior to infection, the fingerling grouper were fed raw small shrimp diet and the adult grouper with commercial pellets. About 20 to 40 tomonts were seeded into 1-L beaker, with one fingerling grouper in each beaker to be infected by the excysting theronts. The propagation of the parasite using the adult grouper was accomplished by infecting the fish in $70-\mathrm{L}$ aquarium with theronts from 1000 tomonts. Salinity of the water was maintained at $3.5 \%$. A moderate aeration was installed in each confinement. The fish hosts were transferred to a new confinement when most of the trophonts, visible as white spots on fish body, had exited and transformed to tomont cysts which settled at the bottom of the beaker and aquarium. The tomonts were collected from the beakers or aquaria, cleaned of any debris and mucus by gentle brushing, pipetting and repeated washes, and transferred to Petri plates.

\subsection{Purification of grouper $I g$}

Blood was taken from grouper (average of $450 \mathrm{~g}$ in body weight) using $10-\mathrm{mL}$ syringe (gauge no. 23) punctured through the sinus artery in the gills. The blood was allowed to clot for $1 \mathrm{~h}$ at room temperature, then overnight at $4{ }^{\circ} \mathrm{C}$ and centrifuged at $1000 \times g$ at $4{ }^{\circ} \mathrm{C}$ for $30 \mathrm{~min}$ to separate the serum. The serum was subsequently stored at $-20{ }^{\circ} \mathrm{C}$ prior to use. 
Grouper Ig was purified using a two-step protocol. Precipitation of Ig from the serum was carried out by slow dropwise addition of saturated ammonium sulphate to the serum, while shaking, to a final concentration of $50 \%(\mathrm{v} / \mathrm{v})$. Separation of the precipitate was done by centrifugation at $10,000 \times \mathrm{g}$ for $15 \mathrm{~min}$. The precipitate was resuspended in $1 \mathrm{~mL}$ of $0.02 \mathrm{M} \mathrm{PBS}(\mathrm{pH} 8.0)$ and dialyzed at $4{ }^{\circ} \mathrm{C}$ overnight with a single change of $0.02 \mathrm{M}$ PBS. The dialyzed solution was loaded onto DEAE cellulose ion exchange column (Sigma, USA) preequilibrated with PBS (0.02 M, pH 8.0). After flowing with PBS $(0.02 \mathrm{M})$, grouper Ig was eluted with $0.2 \mathrm{M}$ PBS (pH 8.0). Grouper Ig was characterized to contain a $78 \mathrm{kDa} \mathrm{H}$ chain and $30 \mathrm{kDa}$ L chain by SDS-PAGE (8$25 \%$ phastgel) and the molecular weight was calculated to be $846 \mathrm{kDa}$ by native PAGE (10-15\% phastgel).

\subsection{Preparation of rabbit antiserum against grouper Ig}

A New Zealand white female rabbit (3 $\mathrm{kg}$ in body weight) received a subcutaneous injection of the purified $500 \mu \mathrm{g}$ grouper Ig emulsified with an equal volume of Freund's complete adjuvant (Difco). One week apart, the rabbit was boostered with $500 \mu \mathrm{g}$ Ig emulsified with an equal volume of Freund's incomplete adjuvant (Difco). Blood was withdrawn from the rabbit's cervical artery 4 weeks after the booster injection and clotted for $1 \mathrm{~h}$ at room temperature and then overnight at $4{ }^{\circ} \mathrm{C}$. Rabbit antiserum was prepared by centrifugation at $1000 \times g$ for $30 \mathrm{~min}$. After which, the antiserum was heat inactivated at $56{ }^{\circ} \mathrm{C}$ for $30 \mathrm{~min}$ and stored at $-20^{\circ} \mathrm{C}$ prior to use. The specificity of the rabbit antibody against grouper Ig was characterized by Western blotting of grouper serum.

\subsection{Exposure-immunization of fish to live C. irritans}

A low level exposure of $E$. coioides to $C$. irritans theronts from predetermined number of tomonts was carried out. The grouper immunized by means of a low level exposure to live theronts was described here as exposure-immunized. In brief, a pretest was carried out to determine the number of mature tomonts in which the excysting theronts would cause low level of infection without causing high fish mortality. Based on the pretest result, the numbers of tomonts to be seeded in the exposure-immunization of fingerling grouper $(3-5 \mathrm{~cm}$ in length) in 20-L aquaria were as follows: 0 tomont/fish (unexposed group as control), 40 tomonts/fish and 80 tomonts/fish. Each group consisted of three replicates with 15 fingerlings per replicate. Whereas, two adult grouper (ca. $300 \mathrm{~g}$ each) reared individually in $20-\mathrm{L}$ aquaria were exposed to theronts from 1000 tomonts/fish.

\subsubsection{Immobilization assay on mucus of grouper}

Mucus was collected from $E$. coioides, both the fingerlings and adult, at 3-week post-exposure and from unexposed fish serving as control. The mucus was collected on both lateral sides of the fish by gently wiping the body with cotton swabs and squeezing the mucus into Eppendorf tubes. The mucus of the fingerlings in each replicate per group was pooled in the Eppendorf tubes. For the adult grouper, the fish were first anesthesized by immersion into $10 \mathrm{~L}$ of seawater in a bucket with $10 \mathrm{~mL}$ of ethylene glycohol monophenyl ether. Mucus collection was then carried out as above. No pooling of mucus was done for adult fish. Heating of the mucus to inactivate the complement was carried out at $45{ }^{\circ} \mathrm{C}$ for $20 \mathrm{~min}$. The mucus was subsequently stored in $-80^{\circ} \mathrm{C}$ before use. The immobilization of the $C$. irritans theronts in mucus was assessed in 96-U well plates in serial dilution.

\subsubsection{Enzyme-linked immunosorbent assay}

A standard protocol for ELISA was followed in assessing the presence of antibodies in the mucus of exposure-immunized E. coioides fingerling and adult grouper. Sonicated C. irritans theront antigens $(5 \mu \mathrm{g} / \mathrm{mL}$ proteins) in phosphate buffered saline (PBS, $0.01 \mathrm{M}$ ) were diluted in carbonate buffer $\left(0.05 \mathrm{M} \mathrm{Na}_{2} \mathrm{CO}_{3}\right.$ and $0.05 \mathrm{M}$ $\mathrm{NaHCO}_{3}, \mathrm{pH}$ 9.6) and coated on to ELISA microtitre plates with $100 \mu \mathrm{L}$ of diluted antigens added into each well. The plates were incubated at $37^{\circ} \mathrm{C}$ for $1 \mathrm{~h}$ and after which the wells were washed five times with PBS containing $0.1 \%$ Tween 20 (PBS-T, pH 8.0) using an automatic plate washer (Dynatech Medical Products Ltd., Great Britain). The plates were blocked with $150 \mu \mathrm{L}$ gelatin-NET buffer per well $(0.25 \%$ gelatin, $0.15 \mathrm{M} \mathrm{NaCl}$, $5 \mathrm{mM}$ EDTA, $0.05 \%$ Tween, $50 \mathrm{mM}$ Tris-base) and incubated at $37^{\circ} \mathrm{C}$ for $1 \mathrm{~h}$. After five washes with PBS-T, a two-fold dilution series with gelatin-NET was made for the mucus of grouper, added into the plates at $100 \mu \mathrm{L} /$ well and incubated as before. PBS alone served as the control. The plates were washed and fish antibodies were detected with rabbit antiserum against grouper Ig diluted 100-fold with gelatin-NET. The incubation of plates and washes were performed as before. Alkaline phosphatase-conjugated goat anti-rabbit IgG (Kirkegaard and Perry Laboratories, KPL) diluted 2000-fold with gelatin-NET was added at $100 \mu \mathrm{L}$ into each well. The plates were then incubated and washed. After which $100 \mu \mathrm{L}$ of a color presenting solution (1 mg 4-nitrophenyl phosphate $/ \mathrm{mL}$ of diethanolamine HCl-buffer) was added into each well and incubated for $30 \mathrm{~min}$ at room temperature. After addition of $50 \mu \mathrm{L}$ of $3 \mathrm{M} \mathrm{NaOH}$ into each well, the optical density values were read at $405 \mathrm{~nm}$ using an ELISA reader (Emax, Molecular Devices). 


\subsubsection{Repeated exposures of adult grouper to C. irritans}

To determine the effect of repeated exposures of the same fish to the tomont size of C. irritans, we subjected three adult grouper (ca. $300 \mathrm{~g}$ each) to three successive low level exposures in separate aquaria. The first exposure of grouper to $C$. irritans theronts was carried out by seeding 1000 tomonts/fish into each of the aquaria. After the exit of the parasites which settled as tomonts, each fish was carefully transferred to another aquarium and 1000 tomonts produced from the first exposure were seeded for the second successive exposure of the same fish to theronts. The procedure was repeated until the third successive exposure of the same fish to theronts. Tomonts produced from the grouper after its third successive exposure were then seeded into a separate aquarium with a naïve adult grouper at 1000 tomonts/ fish. Sizes of tomonts produced from the adult grouper after the third successive exposure and from the naïve adult grouper were determined and compared.

\subsection{Vaccine-immunization of fingerling grouper}

The vaccine used in the present study was prepared by formalin fixing of theronts of $C$. irritans. Briefly, theronts were collected from the culture plates and fixed in $8 \%$ neutral buffered formalin. The fixed theronts were incubated at room temperature $\left(26\right.$ to $28{ }^{\circ} \mathrm{C}$ ) for $2 \mathrm{~h}$, and concentrated by centrifugation at $1000 \times g$ for $10 \mathrm{~min}$ at $4{ }^{\circ} \mathrm{C}$. After three washes with $0.02 \mathrm{M}$ phosphate buffered saline (PBS) and centrifugation after each wash, the theront vaccine was freeze dried and stored in $-80{ }^{\circ} \mathrm{C}$ prior to use. Fingerling grouper (each weighing $2.6 \mathrm{~g}$ ) used in the vaccination experiment were procured from a grouper hatchery in southern Taiwan. The fingerling grouper immunized with vaccine against $C$. irritans were described here as vaccine-immunized.

Vaccine-immunization of $E$. coioides fingerlings was performed with two replicates in succession at temperature range from 26 to $28^{\circ} \mathrm{C}$. The vaccine was diluted with PBS and homogenized. Prior to injection, fingerling grouper were anesthesized by immersing the fish into 2-L seawater with $1 \mathrm{~mL}$ of ethylene glycohol monophenyl ether. The fish were divided into three groups with 10 fish (first replicate) and 12 fish (second replicate) in each group. Each fish in the first group received a high dose of $100 \mu \mathrm{g}$ of vaccine (total protein concentration of $3.46 \mu \mathrm{g}$ ) and the second group had a low dose of $10 \mu \mathrm{g}$ (total protein concentration of $0.346 \mu \mathrm{g}$ ). There was no low dose treatment in the second replicate due to insufficient amount of vaccine. The fish in the third group were injected with PBS alone as control. Each fish was injected intraperitoneally with $0.1 \mathrm{~mL}$ of either the vaccine or PBS.
Each group in the second replicate was communally reared first in a moderately aerated aquarium with $50 \mathrm{~L}$ of seawater because prolonged rearing of fingerling grouper in 1-L beakers, as we encountered in our previous studies, caused the excreta to pollute the medium as evidenced by water becoming turbid and by foul smell.

A pretest was conducted to determine the number of seeded tomonts in which the infecting theronts would cause $60 \%$ mortality in fish and in which such dose would be tried in the challenge test. Thus, in the challenge test, $20 \mathrm{C}$. irritans tomonts/fish which became available at 25-day post-immunization were seeded into each aquarium of the first replicate while the second replicate had 80 tomonts/fish seeded in each aquarium at 17-day post-immunization. Fish behaviour and mortality were monitored daily.

At 3-day post-challenge, the fish from the second replicate were transferred individually to $1-\mathrm{L}$ beakers. At 5-day post-challenge, four fish in each group were sacrificed by fixing in $8 \%$ neutral buffered formalin to quantify the trophonts on the fish body. The tomonts that settled at the bottom of the beaker were collected and enumerated.

\subsection{Statistical analysis}

Antibody titers of the grouper mucus were evaluated using analysis of variance (ANOVA) and the significance of the differences between groups was determined using Tukey's HSD test. The differences in the numbers of trophonts and tomonts were analyzed using Student's $t$-test.

\section{Results}

\subsection{Exposure-immunization of grouper}

\subsubsection{Immobilization assay}

The determination of titers considered the reciprocal of highest dilution in which $100 \%$ theronts were immobilized. Results showed no 100\% immobilization of $C$. irritans after $4 \mathrm{~h}$ in $\mathrm{U}$-well plates using the heatinactivated mucus of the control and exposure-immunized fingerling grouper E. coioides. Immobilization titers (titer of 2) were noted in the mucus of the exposureimmunized adult grouper. No immobilization of theronts was observed in the mucus of unexposed control fish (Fig. 1a). Clusters or large mass of aggregated and immobilized theronts was observed in the mucus of the exposure-immunized grouper at low dilutions (Fig. 1b), while aggregation at higher dilutions was not observed. 


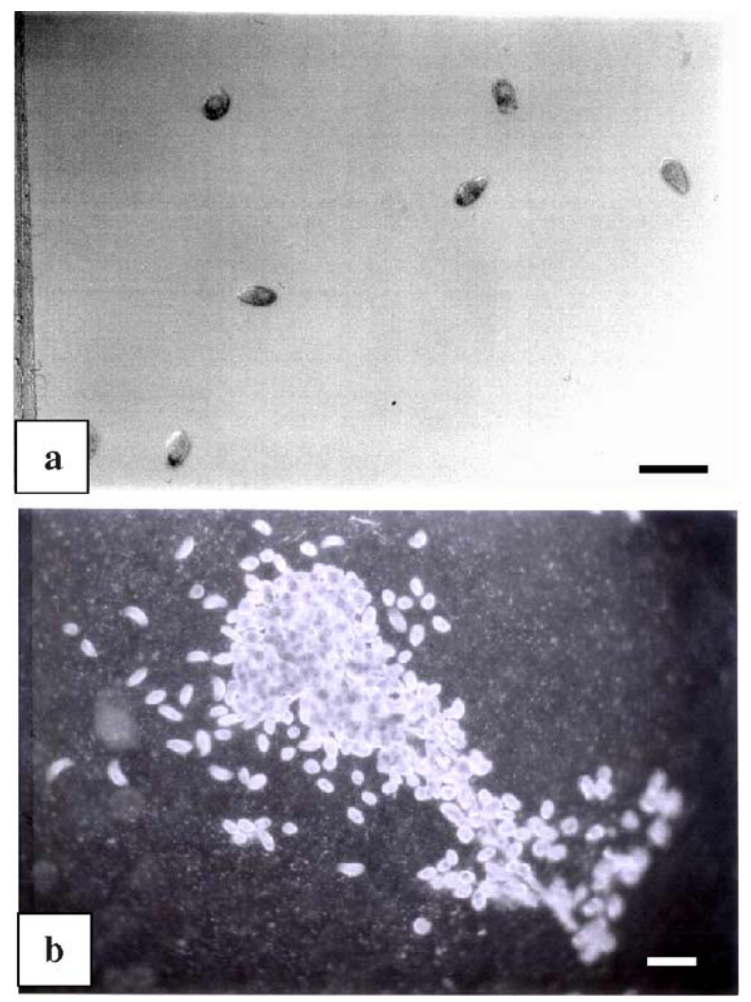

Fig. 1. Immobilization assay showed active swimming of C. irritans theronts (a) in the mucus of uninfected adult grouper (scale bar $=100 \mu \mathrm{m}$ ), while aggregation of theronts (b) was observed in the mucus of exposure-immunized adult grouper at 3-week post-exposure (scale bar $=100 \mu \mathrm{m}$ ).

\subsubsection{Enzyme-linked immunosorbent assay}

Since no titer (mucus of fingerling grouper) or low titers (mucus of adult grouper) were detected in the immobilization assay, ELISA was used to detect the antibody titers in the mucus of fish at 3-week postexposure. Results showed that the antibody titers were significantly higher in the mucus of both groups of exposure-immunized fingerling grouper than the control groups up to 512 dilution (Fig. 2a) $(p<0.01$, Tukey's HSD test). Fingerling grouper that were previously exposed to $C$. irritans theronts from 80 tomonts/fish had the highest antibody titers up to 512 dilution, which were significantly different from the group that had prior exposure to theronts from 40 tomonts/fish (except at 16 dilution) and the control ( $p<0.01$, Tukey's HSD test).

The antibody titers for the mucus of two adult grouper with previous exposure to theronts from 1000 tomonts/ fish and of unexposed grouper at 3-week post-exposure are shown in Fig. 2b. The antibody titers of the mucus from fish 3 with prior exposure to theronts were significantly different from unexposed fish 1 in all dilutions
( $p<0.01$, Tukey's HSD test). The titers for fish 2 were significantly different from the unexposed fish 1 except at higher dilutions from 512 onward. The titers for fish 2 and fish 3 were not significantly different from each other except at 128, 256, 512 and 2048 dilutions.

\subsubsection{Sizes of tomonts after three successive exposures to C. irritans}

Sizes of trophonts on the body of adult grouper were apparently smaller in the adult grouper after three successive exposures than those of the trophonts appearing on fish after single exposure. To confirm the decrease in
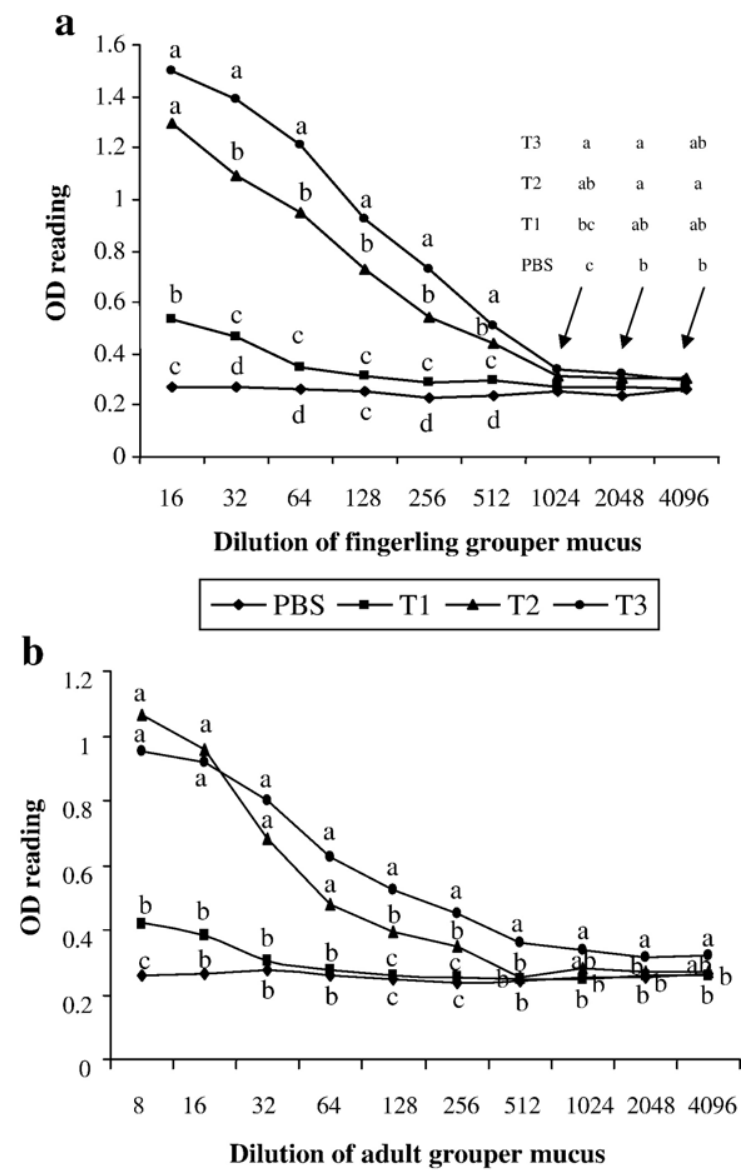

$\leftarrow$ PBS $\rightarrow$ Fish $1 \leftarrow$ Fish $2 \rightarrow$ Fish 3

Fig. 2. Optical density readings (means of three replicates) of fingerling grouper mucus (a) and adult grouper mucus (b) at various dilutions using ELISA at 3-week post-exposure. Those with different letters are significant (Tukey's HSD test, $p<0.01$ ). (PBS-control, T1unexposed fingerlings, T2-fingerlings exposed to theronts from 40 tomonts/fish, T3-fingerlings exposed to theronts from 80 tomonts/fish. Exposure of adult grouper to live C. irritans was done with theronts from 1000 tomonts.). 
Table 1

Percent cumulative mortality of vaccine-immunized fingerling grouper challenged with $C$. irritans theronts from 20 tomonts/fish and from 80 tomonts/fish at 22-day and 9-day post-challenge, respectively

\begin{tabular}{|c|c|c|c|}
\hline & \multicolumn{3}{|c|}{ Vaccine dose } \\
\hline & $\begin{array}{l}100 \mu \mathrm{g} / \\
\text { fish }\end{array}$ & $\begin{array}{l}10 \mu \mathrm{g} / \\
\text { fish }^{\mathrm{a}}\end{array}$ & $\begin{array}{l}\text { Control } \\
\text { (PBS) }\end{array}$ \\
\hline \multicolumn{4}{|l|}{$\%$ cumulative mortality } \\
\hline $\begin{array}{l}20 \text { tomonts/fish, } 22 \text {-day post- } \\
\text { challenge }(n=10)\end{array}$ & 0 & 40 & 90 \\
\hline $\begin{array}{l}80 \text { tomonts/fish, 9-day post- } \\
\text { challenge }(n=8)\end{array}$ & 37.5 & ND & 100 \\
\hline $\begin{array}{l}\text { Total number of tomonts at } 5 \text {-day } \\
\text { post-challenge }(n=12)\end{array}$ & 0 & ND & 1830 \\
\hline $\begin{array}{l}\text { Mean number of trophonts at 5-day } \\
\text { post-challenge }(n=4)\end{array}$ & $\begin{array}{l}36.75 \pm \\
11.56^{\mathrm{a}}\end{array}$ & ND & $\begin{array}{l}107.75 \pm \\
60.22^{\mathrm{b}}\end{array}$ \\
\hline $\begin{array}{l}\text { Mean number of tomonts at 7-day } \\
\text { post-challenge }(n=3)\end{array}$ & $\begin{array}{l}81.67 \pm \\
22.28^{\mathrm{a}}\end{array}$ & ND & $\begin{array}{l}202.67 \pm \\
81.65^{\mathrm{b}}\end{array}$ \\
\hline
\end{tabular}

Numbers of tomonts and trophonts produced in the vaccineimmunized and control (PBS-injected) fingerling grouper after challenge are shown. Means with different superscript letters are significantly different (Student's $t$-test, $p<0.05$ ).

${ }^{\text {a }}$ ND: not determined.

size, the tomonts produced from the adult grouper after third exposure were used to infect a naïve grouper. The sizes of tomonts $(321 \mu \mathrm{m} \pm 46.52, n=30)$ produced from the same grouper after the three successive exposures were significantly smaller than the sizes of tomonts (448 $\mu \mathrm{m} \pm 54.49, n=30$ ) produced from the succeeding generation that infected the naïve grouper $(p<0.01$, Student's $t$-test).

\subsection{Vaccine-immunization of fingerling grouper}

No mortality was monitored on the vaccine-immunized fingerling grouper that received a high dose vaccine (100 $\mu \mathrm{g} /$ fish, $n=10)$ at 22-day post-challenge while cumulative mortalities of $40 \%$ and $90 \%$ were recorded in the groups that received the low dose vaccine $(10 \mu \mathrm{g} /$ fish $)$ and the PBS-injection (control), respectively (Table 1). In the replicate, cumulative fish mortalities of $37.5 \%$ in the vaccine-immunized group and $100 \%$ in the control group were observed at 9-day post-challenge (Table 1). A total of 1830 tomonts was collected in the control group while no tomont was produced in the vaccine-immunized group at 5-day post-challenge. In addition, significantly fewer trophonts $(36.75 \pm 11.564)$ on the vaccine-immunized fish than the PBS-injected fish $(107.75 \pm 60.22)$ were enumerated at 5-day post-challenge ( $p<0.05$, Student's $t$-test). Also, significantly fewer tomonts $(81.67 \pm 22.28)$ were produced in the vaccine-immunized fish than the PBSinjected group (202.67 \pm 81.65$)$ at 7-day post-challenge.

\section{Discussion}

The present study used a commercially important and high-value cultured grouper E. coioides as host of the parasite. The results demonstrated that the immunization of grouper either by a low level exposure of the fish to live $C$. irritans theronts or an injection of formalin-killed C. irritans conferred a protective immunity to fish.

The immobilization of $C$. irritans theronts is generally shown by the loss of swimming movement, limited ciliary beating and rounding of cells with or without cell aggregation. In a number of studies, mucus antibodies against the freshwater counterpart I. multifiliis were not detectable in immobilization assays possibly because the concentration was not sufficient enough to immobilize the theronts in vitro; however, the antibody titers in the mucus were detected by ELISA (Sin et al., 1996; Wang and Dickerson, 2002; Maki and Dickerson, 2003; $\mathrm{Xu}$ et al., 2004). The present study which showed that the levels of the antibody titers in the mucus of the grouper fingerlings immunized by the low level exposure to $C$. irritans theronts positively correlated with the number of the infecting parasites is in agreement with Burgess and Matthews (1995).

Lobb and Clem (1981) demonstrated that the Ig in the cutaneous mucus and bile were not due to transudation or active transport of serum Ig. However, there is a positive relationship between the fish mucosal antibodies and serum antibodies (Cain et al., 2000; LaFrentz et al., 2002; Esteve-Gassent et al., 2003). The possibility that the mucosal antibodies are produced locally in the skin has been suggested, although there is no evidence yet on the presence of antibody-secreting lymphocytes or lymphoid tissues in or outside the skin (Dickerson and Clark, 1998; Hatten et al., 2001; Esteve-Gassent et al., 2003; Maki and Dickerson, 2003). It was demonstrated though that cutaneous antibodies present in excised skin or secreted in water from channel catfish immune to I. multifiliis could immobilize or weaken the theronts (Xu and Klesius, 2002, 2003; Xu et al., 2002).

The decrease in size of the C. irritans trophonts on fish body and the tomonts produced after three successive exposures of the same grouper indicates a stunting effect of immunization on the development and growth of trophonts on fish host. This is corroborated by $\mathrm{Xu}$ and Klesius (2002) who reported that the theronts of $I$. multifiliis treated with a culture fluid from an immune fish transformed into smaller trophonts compared with trophonts from a control fish. It is also possible that the development of the parasite was affected by their early exit from the immunized fish and the sooner they exit, 
the smaller the tomonts would be (Cross and Matthews, 1992; Clark et al., 1996; Clark and Dickerson, 1997).

Since the antibodies were shown to be enhanced in a low level exposure of grouper to $C$. irritans theronts, it was then necessary to assess whether protection is conferred by vaccine-immunization. Several studies carried out the immunization of fish by injection of antigens of C. irritans (Bryant et al., 1999) and of I. multifiliis (Sin et al., 1996; He et al., 1997; Dalgaard et al., 2002; Wang and Dickerson, 2002; Wang et al., 2002; Maki and Dickerson, 2003; Xu et al., 2004). Various authors also reported the immunization by exposures of fish to predetermined number of $C$. irritans theronts (Burgess and Matthews, 1995; Yoshinaga and Nakazoe, 1997) and $I$. multifiliis (Cross and Matthews, 1992, 1993; Houghton and Matthews, 1993; Gleeson et al., 2000; Sigh and Buchmann, 2001; Xu et al., 2003). Both immunization routes resulted to higher titers of the mucosal and serum antibodies compared to the control. However, the vaccine-immunization of fish has more practical application in aquaculture than an immunization by low level exposure of fish to $C$. irritans theronts.

The lower cumulative mortality of the vaccine-immunized fingerling grouper compared to the control in the immunization experiment also indicates that a protective immunity was conferred to the immunized grouper. A mortality of $90 \%$ was recorded in one control group at 22-day post-challenge, while $100 \%$ mortality was noted in the replicate control group at 9-day postchallenge. The almost equal cumulative mortalities of $40 \%$ (vaccine dose of $10 \mu \mathrm{g} / \mathrm{fish}$ ) in one replicate and $37.5 \%$ (vaccine dose of $100 \mu \mathrm{g} /$ fish) in the other replicate indicate that using the lower dose in the vaccineimmunization of fish will have comparable result with the higher dose. C. irritans is known to have an asynchronous tomont development even under the same conditions and the tomonts usually undergo division to produce the theronts within a broad span of 3 to 72 days (Colorni, 1985, 1987; Burgess and Matthews, 1994; Yoshinaga and Dickerson, 1994; Diggles and Lester, 1996). In spite of the difference in the number of days of monitoring the mortality, the highest survival was still achieved in both vaccine-immunized groups (low dose of $10 \mu \mathrm{g} /$ fish and high dose of $100 \mu \mathrm{g} /$ fish) suggesting the positive effect of immunization.

The establishment of few C. irritans trophonts at 5-day post-challenge, the absence of tomonts at 5-day postchallenge and the presence of few tomonts at 7-day postchallenge in the vaccine-immunized fish in comparison to the control also indicate other mechanisms by which the protective immunity was conferred on fish. The immunity limited the adhesion, penetration and development of the
C. irritans theronts. Similarly, fewer trophonts on the body of $C$. irritans-exposed mullet Chelon labrosus than the control was recorded by Burgess and Matthews (1995). Yoshinaga and Nakazoe (1997) also mentioned a significant difference in the intensity of infection between C. irritans-exposed and control groups of mummichog Fundulus heteroclitus.

In I. multifiliis, Houghton and Matthews (1993) mentioned that the trophonts that would have established on fish might have died or exited while Clark et al. (1996) suggested that a substantial number of parasites might have been killed on the fish after antibody binding. The early exit of the parasite from the immunized fish host has been suggested as a possible result of avoidance response on the part of I. multifiliis at an antibody concentration which is subthreshold for immobilization or of antibody binding at the surface of the parasite that signals it to leave the fish host (Cross and Matthews, 1992; Clark et al., 1995, 1996; Clark and Dickerson, 1997). This may explain why fewer $C$. irritans tomonts and trophonts were enumerated in the vaccine-immunized grouper.

To conclude, the response of immunized grouper $E$. coioides either by exposure to $C$. irritans theronts or injection of formalin-killed $C$. irritans suggests that an acquired protective immunity had been conferred. The evidences included higher antibody titers in the mucus of the exposure-immunized fish and higher fish survival and fewer trophonts and tomonts in the vaccineimmunized fish than the control groups. The antibody titers increased with an increase in the number of parasite used in the exposure. The antibodies from the skin of the fish may have prevented the adhesion, invasion and development of $C$. irritans theronts; those that developed were fewer or even smaller than the control. Cellular immunity may play a role in the defense of fish but the antibodies appear vital in providing a complete protection of grouper against $C$. irritans.

\section{Acknowledgements}

The authors thank the Council of Agriculture, Taiwan (92AS-9.2.2-FA-F1) for financially supporting the research project. We also thank Dr. In-Cho Lee for the statistical analysis of the data.

\section{References}

Bryant, M.S., Lee, R.P., Lester, R.J.G., Whittington, R.J., 1999. Antiimmunoglobulin antisera used in an ELISA to detect antibodies in barramundi Lates calcarifer to Cryptocaryon irritans. Dis. Aquat. Org. 36, 21-28.

Burgess, P.J., Matthews, R.A., 1994. A standardized method for the in vivo maintenance of Cryptocaryon irritans (Ciliophora) using the 
grey mullet Chelon labrosus as an experimental host. J. Parasitol. 80, 288-292.

Burgess, P.J., Matthews, R.A., 1995. Cryptocaryon irritans (Ciliophora): acquired protective immunity in the thick-lipped mullet, Chelon labrosus. Fish Shellfish Immunol. 5, 459-468.

Burkart, M.A., Clark, T.G., Dickerson, H.W., 1990. Immunization of channel catfish, Ictalurus punctatus Rafinisque, against Ichthyophthirius multifiliis (Fouquet): killed versus live vaccines. J. Fish Dis. $13,401-410$

Cain, K.D., Jones, D.R., Raison, R.L., 2000. Characterisation of mucosal and systemic immune responses in rainbow trout (Onchorhyncus mykiss) using surface plasmon resonance. Fish Shellfish Immunol. 10, 651-666

Clark, T.G., Dickerson, H.W., 1997. Antibody-mediated effects on parasite behavior: evidence of a novel mechanism of immunity against a parasitic protist. Parasitol. Today 13, 477-480.

Clark, T.G., Dickerson, H.W., Lin, T.L., 1987. In vitro response of Ichthyophthirius multifiliis to sera from immune channel catfish. J. Fish Biol. 31, 203-208.

Clark, T.G., Dickerson, H.W., Findly, R.C., 1988. Immune response of channel catfish to ciliary antigens of Ichthyophthirius multifiliis. Dev. Comp. Immunol. 12, 581-594.

Clark, T.G., Lin, T.L., Dickerson, H.W., 1995. Surface immobilization antigens of Ichthyophthirius multifiliis: their role in protective immunity. Annu. Rev. Fish Dis. 5, 113-131.

Clark, T.G., Lin, T.L., Dickerson, H.W., 1996. Surface antigen crosslinking triggers forced exit of a protozoan parasite from its host. Proc. Natl. Acad. Sci. 93, 6825-6829.

Colorni, A., 1985. Aspects of the biology of Cryptocaryon irritans, and hyposalinity as a control measure in cultured gilt-head sea bream Sparus aurata. Dis. Aquat. Org. 1, 19-22.

Colorni, A., 1987. Biology of Cryptocaryon irritans and strategies for its control. Aquaculture 67, 236-237.

Colorni, A., Burgess, P.J., 1997. Cryptocaryon irritans Brown 1951, the cause of white spot disease in marine fish: an update. Aquar. Sci. Conserv. 1, 217-238.

Cross, M.L., Matthews, R.A., 1992. Ichthyophthiriasis in carp, Cyprinus carpio L.: fate of parasites in immunized fish. J. Fish Dis. 15, 497-505.

Cross, M.L., Matthews, R.A., 1993. Ichthyophthirius multifiliis Fouquet (Ciliophora): the location of sites immunogenic to the host Cyprinus carpio (L.). Fish Shellfish Immunol. 3, 13-24.

Dalgaard, M., Buchmann, K., Li, A., 2002. Immunization of rainbow trout fry with Ichthyophthirius multifiliis sonicate: protection of host and immunological changes. Bull. Eur. Assoc. Fish Pathol. 22, 288-297.

Dickerson, H.W., Clark, T.G., 1998. Ichthyophthirius multifiliis: a model of cutaneous infection and immunity in fishes. Immunol. Rev. 166, 377-384.

Dickerson, H.W., Clark, T.G., Findly, R.C., 1989. Ichthyophthirius multifiliis has membrane-associated immobilization antigens. J. Protozool. 36, 159-164.

Diggles, B.J., Adlard, R.D., 1997. Intraspecific variation in Cryptocaryon irritans. J. Eukaryot. Microbiol. 44, 25-32.

Diggles, B.J., Lester, J.G., 1996. Variation in the development of two isolates of Cryptocaryon irritans. J. Parasitol. 82, 384-388.

Esteve-Gassent, M.D., Nielsen, M.E., Amaro, C., 2003. The kinetics of antibody production in mucus and serum of European eel (Anguilla anguilla) after vaccination against Vibrio vulnificus: development of a new method for antibody quantification in skin mucus. Fish Shellfish Immunol. 15, 51-61.

Gleeson, D.J., McCallum, H.I., Owens, I.P.F., 2000. Differences in initial and acquired resistance to Ichthyophthirius multifiliis between populations of rainbowfish. J. Fish Biol. 57, 466-475.
Hatten, F., Frederiksen, A., Hordvik, I., Endersen, C., 2001. Presence of IgM in cutaneous mucus, but not in gut mucus of Atlantic salmon, Salmo salar. Serum IgM is rapidly degraded when added to gut mucus. Fish Shellfish Immunol. 11, 257-268.

He, J., Yin, Z., Xu, G., Gong, Z., Lam, T.J., Sin, Y.M., 1997. Protection of goldfish against Ichthyophthirius multifiliis by immunization with a recombinant vaccine. Aquaculture 158, 1-10.

Houghton, G., Matthews, R.A., 1993. Ichthyophthirius multifiliis (Fouquet): survival within immune juvenile carp, Cyprinus carpio L. Fish Shellfish Immunol. 3, 157-166.

LaFrentz, B.R., LaPatra, S.E., Jones, G.R., Congleton, J.L., Sun, B., Cain, K.D., 2002. Characterisation of serum and mucosal antibody responses and relative per cent survival in rainbow trout, Onchorhyncus mykiss (Walbaum), following immunization and challenge with Flavobacterium psychrophilum. J. Fish Dis. 25, 703-713.

Lin, T.L., Dickerson, H.W., 1992. Purification and partial characterization of immobilization antigens from Ichthyophthirius multifiliis. J. Protozool. 39, 457-463.

Lobb, C.J., Clem, L.W., 1981. The metabolic relationships of the immunoglobulins in fish serum, cutaneous mucus, and bile. J. Immunol. 127, 1525-1529.

Maki, J.L., Dickerson, H.W., 2003. Systemic and cutaneous mucus antibody responses of channel catfish immunized against the protozoan parasite Ichthyophthirius multifiliis. Clin. Diagn. Lab. Immunol. 10, 876-881.

Rasheed, V.M., 1989. Diseases of cultured brown-spotted grouper Epinephelus tauvina and silvery jack porgy Acanthopagrus cuvieri in Kuwait. J. Aquat. Anim. Health 1, 102-107.

Sigh, J., Buchmann, K., 2001. Comparison of immobilization assays and enzyme-linked immunosorbent assays for detection of rainbow trout antibody-titres against Ichthyophthirius multifiliis Fouquet, 1876. J. Fish Dis. 24, 49-51.

Sigh, J., Buchmann, K., 2002. Comparative analysis of cross-reactivity between Ichthyophthirius and Tetrahymena. Bull. Eur. Assoc. Fish Pathol. 22, 37-44.

Sin, Y.M., Ling, K.H., Lam, T.J., 1996. Cell-mediated response of goldfish, Carassius auratus (L.), to Ichthyophthirius multifiliis. J. Fish Dis. 19, 1-7.

Wang, X., Dickerson, H.W., 2002. Surface immobilization antigen of the parasitic ciliate Ichthyophthirius multifiliis elicits protective immunity in Channel catfish (Ictalurus punctatus). Clin. Diagn. Lab. Immunol. 9, 176-181.

Wang, X., Clark, T.G., Noe, J., Dickerson, H.W., 2002. Immunisation of channel catfish, Ictalurus punctatus, with Ichthyophthirius multifiliis immobilization antigens elicits serotype-specific protection. Fish Shellfish Immunol. 13, 337-350.

Wright, A.D.G., Colorni, A., 2002. Taxonomic re-assignment of Cryptocaryon irritans, a marine fish parasite. Eur. J. Protistol. 37, 375-378.

Xu, D.H., Klesius, P.H., 2002. Antibody mediated immune response against Ichthyophthirius multifiliis using excised skin from channel catfish, Ictalurus punctatus (Rafinesque), immune to Ichthyophthirius. J. Fish Dis. 25, 299-306.

Xu, D.H., Klesius, P.H., 2003. Protective effect of cutaneous antibody produced by channel catfish, Ictalurus punctatus (Rafinesque), immune to Ichthyophthirius multifiliis Fouquet on cohabited nonimmune fish. J. Fish Dis. 26, 287-291.

Xu, C.H., Clark, T.G., Leff, A.A., Dickerson, H.W., 1995. Analysis of the soluble and membrane-bound immobilization antigens of Ichthyophthirius multifiliis. J. Eukaryot. Microbiol. 42, 558-564.

Xu, D.H., Klesius, P.H., Shelby, R.A., 2002. Cutaneous antibodies in excised skin from channel catfish, Ictalurus punctatus (Rafinesque), immune to Ichthyophthirius multifiliis. J. Fish Dis. 25, 45-52. 
Xu, D.H., Klesius, P.H., Shelby, R.A., 2003. A modified enzyme-linked immunosorbent assay for detection of cutaneous antibody against Ichthyophthirius multifiliis. Bull. Eur. Assoc. Fish Pathol. 23, 228-234.

Xu, D.H., Klesius, P.H., Shelby, R.A., 2004. Immune responses and host protection of channel catfish, Ictalurus punctatus (Rafinesque), against Ichthyophthirius multifiliis after immunization with live theronts and sonicated trophonts. J. Fish Dis. 27, 135-141.

Yambot, A.V., Song, Y.L., Sung, H.H., 2003. Characterization of Cryptocaryon irritans, a parasite isolated from marine fishes in Taiwan. Dis. Aquat. Org. 54, 147-156.
Yoshinaga, T., Dickerson, H.W., 1994. Laboratory propagation of Cryptocaryon irritans on a saltwater adapted Poecilia hybrid, the Black Molly. J. Aquat. Anim. Health 6, 197-201.

Yoshinaga, T., Nakazoe, J., 1997. Acquired protection and production of immobilization antibody against Cryptocaryon irritans (Ciliophora, Hymenostomatida) in mummichog (Fundulus heteroclitus). Fish Pathol. 32, 229-230. 